\title{
Four Poems: Then and Now
}

\section{John Keats (1795-1821)}

\section{When I Have Fears That I May Cease to Be}

When I have fears that I may cease to be

Before my pen has gleaned my teeming brain,

Before high-piled books, in charactery,

Hold like rich garners the full-ripen'd grain;

When I behold, upon the night's starred face,

Huge cloudy symbols of a high romance,

And think that I may never live to trace

Their shadows, with the magic hand of chance,

And when I feel, fair creature of an hour,

That I shall never look upon thee more,

Never have relish in the faery power

Of unreflecting love;--then on the shore

Of the wide world I stand alone, and think

Till love and fame to nothingness do sink. 


\section{John Keats (1795-1821)}

\section{Lines on the Mermaid Tavern}

Souls of poets, dead and gone,

What Elysium have ye known,

Happy field or Mossy Cavern,

Choicer than the Mermaid Tavern?

Have ye tippled drink more fine

Than mine host's Canary wine?

Or are fruits of paradise

Sweeter than those dainty pies

Of venison? O generous food!

Drest as though bold Robin Hood

would, with his maid Marian,

Sup and bowse from horn and can. [sic]

I have heard that on a day

Mine host's sign-board flew away,

Nobody knew whither, till

An astrologer's old quill

To a sheepskin gave the story,

Said he saw you in your glory,

Underneath a new-old sign

Sipping beverage divine,

And pledging with contented smack

The Mermaid in the Zodiac.

Souls of poets, dead and gone,

What Elysium have ye known,

Happy field or Mossy Cavern,

Choicer than the Mermaid Tavern? 


\section{Charles Baudelaire (1821-1867)}

\section{Man and the Sea ${ }^{1}$}

Free Man, yes, you will always love the sea.

The ocean is your mirror; you see your soul

like breakers infinitely crest and roll;

your mind, a gulf, flows not less bitterly.

You like to dive into that glass; you hold

its motions by your arms, your eyes; your heart

is charmed from its own murmur as a part

of you to hear that plaint, untamed, wild, bold!

You both are shadowy, discreet, and deep;

for none has plumbed the truths of your dark pools,

O man; none knows, O sea, your wealth, your jewels, so jealous are you of the lore you keep.

And yet for countless ages you've defied each other, ruthless brothers, without sense, both loving greatly death and violence, eternal strugglers, pitiless, with pride.

1 Translation from the French, from Catharine Savage Brosman, A Memory of Manaus, (c Mercer University Press, 2017. Used by permission. 


\section{Catharine Savage Brosman ${ }^{2}$}

\section{Pat Curating His Library}

It started with Tom Sawyer, from a generous aunt, of foreign birth but knowing all the better what the use of books might be for this bright boy, determined, eager. Decades later, his collection held a dozen copies, maybe more, comprising gifts and other favorites, some well-worn: critical editions, boxed sets with Huckleberry Finn (numerous duplicates of that likewise, in sundry

printings), and translations into German, French, and other tongues. Plus all the rest of Twain, Pat's fellow “Show Me” from Missouri, each a river-man (though Pat, fourteen, was merely an apprentice deck hand). He bought commentaries and biographies-enormous tomes-and Twain's own ramblings, later called "autobiography." All that made a cluster, never separated in Pat's moves, until the move of death and scattering of many books -ashes of the mind. Other clusters: T. E. Lawrence, Faulkner, Irving, RLS, Wolfe, Lindbergh, various odd specimens. Mostly men's authors. But lots of poetry as well, hard-bound, great names both British and American, some French, and poets of our time-Heaney, of course, Sylvia Plath (hardly in my view, whatever others think, a worthy

2 "Catharine Savage Brosman is professor emerita of French at Tulane University; brosman@tulane.edu. Her forthcoming book, Arm-in-Arm: Poems, is set to appear in spring-summer 2022 from Mercer University Press. 
name to stand with those of Wordsworth, Byron, Tennyson, Poe, Eliot, Yeats). And history, explorers! whether on foot, by horse, by sea: the Orient, America, the equatorial latitudes, Near East, the poles. Otherwise, Pat's shelves were in no order-never, perhaps; or such as had obtained once was undone. He had two books out, always, sometimes three, in different rooms and chairs. New items,

many, were at hand, but for the older-valued differently-he often had to search; in doing so, he rearranged some, made discoveries (!), found what he had not wanted, necessarily, but might be just as good, or better. So I see him standing there, before a bookshelf, reading sideways down the spines, or taking out a first book, then a second, checking or comparing,

rectifying misalignment, laying aside a jacket to be mended or discarded (though he held them always in a high regard and preserved them carefully for years-they also should be read, a paratexte). Sometimes I'd ask him for a book, one we knew he owned-or I would help him look, turning here, then there. "What's its color?" "Which edition?"-or he'd find a substitute. I am bereft

of curator, you see, of one who cared tremendouslyfor books, for me-but would have sacrificed the whole collection for my sake. Now, I return the favor as I can, bestowing on him fresh creations-full of his own Irish spirit, often. I select a gorgeous book of his, leaf through, and find the makings of new poems and the reason I should make them, writing, shaping tombs in words. 